\title{
Pemberian Beberapa Kombinasi ZPT Terhadap Regenerasi Tanaman Gloxinia (Siningia speciosa) dari Eksplan Batang dan Daun Secara In Vitro
}

\author{
Imelda Jeanette Lawalata* \\ Jurusan Budidaya Pertanian, Fakultas Pertanian Universitas Pattimura
}

\begin{abstract}
Abstrak
Beberapa kombinasi Zat Pengatur Tumbuh (ZPT) seperti auksin, Fulvic acid dan sitokinin dicobakan untuk memacu regenerasi tanaman gloxinia (Siningia speciosa) dari eksplan batang dan daun secara in vitro. Auksin terdiri dari NAA $\left(0,2.5,5.0 \mathrm{mgl}^{-1}\right.$ ), fulvic acid (0 dan $1.0 \mathrm{mgl}^{-1}$ ) serta sitokinin (BA $5 \mathrm{mgl}^{-1}$, Novelgro 5 $\mathrm{mll}^{-1}$, air kelapa 20\%). Setiap perlakuan diulang 10 kali. Hasil penelitian menunjukkan bahwa eksplan yang mendapat perlakuan BA $5 \mathrm{mgl}^{-1}$ (M1) dan perlakuan sitokinin tanpa auksin (M1 - M6) memberikan jumlah tunas yang lebih banyak dibandingkan perlakuan auksin. Jumlah daun tertinggi diperoleh pada Media 3 $\left(\right.$ NAA $0 \mathrm{mgl}^{-1}+$ Fulvic acid $0 \mathrm{mgl}^{-1}+$ Air kelapa 20\%) dan Media $6\left(\mathrm{NAA} 0 \mathrm{mgl}^{-1}+\right.$ Fulvic acid $1 \mathrm{mgl}^{-1}+$ Air $^{-1}$ kelapa 20\%). Hampir semua perlakuan NAA dan Fulvic acid yang dikombinasikan dengan air kelapa menunjukkan pertumbuhan jumlah daun yang lebih tinggi dibandingkan kombinasi perlakuan lainnya.
\end{abstract}

Kata kunci: auksin, fulvic acid, Gloxinia, Siningia speciosa, sitokinin

\section{PENDAHULUAN}

Kondisi ekonomi dan budaya yang semakin baik membuat masyarakat mulai memikirkan halhal yang dapat memenuhi kebutuhan rohani disamping kebutuhan jasmaniahnya, termasuk meningkatnya estetika sejalan dengan meningkatnya pendapatan. Selain itu, kesadaran masyarakat akan pentingnya keasrian lingkungan bagi kehidupan, mendorong peningkatan laju prmintaan tanaman hias dalam pot dan salah satunya adalah gloxinia.

Gloxinia (Siningia speciosa) merupakan tanaman hias yang akhir-akhir ini sangat diminati masyarakat. Daun-daun Gloxinia besar dan berbulu serta bunga berbntuk lonceng dengan warna yang beragam memberi kesan ekslusif sebagai daya tarik tanaman tersebut $[1,2,3,4]$. Namun demikian permintaan akan bunga ini harus diimbangi dengan ketersediaannya. Tanaman ini dapat diperbanyak dengan benih, stek daun dan anakan. Teknik tersebut tidak cukup banyak menghasilkan tanaman serta membutuhkan waktu yang lama untuk mendapatkan tanaman berbunga. Salah satu alternatif memperbanyak suatu tanaman

\footnotetext{
* Alamat Korespondensi:

Imelda Jeanette Lawalata

E-mail : Jeanette_nona@yahoo.com

Alamat : Fakultas Pertanian Jurusan Budidaya Pertanian, Universitas Pattimura Ambon, Jl. Ir. M. Putuhena Poka Ambon 97233
}

termasuk gloxinia dapat dilakukan dengan teknik kultur jaringan [5].

Kultur jaringan merupakan suatu metode untuk mengisolasi bagian tanaman, seperti protoplasma, sel, sekelompok sel, jaringan atau organ serta menumbuhkannya dalam kondisi aseptik sehingga bagian-bagian tersebut dapat memperbanyak diri dan beregenerasi menjadi tanaman utuh kembali [6]. Melalui teknik ini bibit dapat diproduksi dalam jumlah yang besar, seragam, bebas hama dan penyakit serta penyediaannya secara kontinyu. Teknik ini juga memungkinkan manipulasi sel dan molekul untuk memperbaiki sifat tanaman serta mempertinggi produksi dan kualitasnya [7].

Zat pengatur tumbuh merupakan senyawa organik bukan nutrisi tanaman, aktif dalam konsentrasi rendah yang merangsang, menghambat atau merubah pertumbuhan serta perkembangan tanaman secara kuantitatif maupun kualitatif. Penggunaan jenis dan konsentrasi zat pengatur tumbuh tertentu dapat mengatur arah pertumbuhan suatu tanaman [8].

Auksin merupakan salah satu golongan ZPT yang cukup penting dalam pertumbuhan tanaman. Auksin berperan dalam mempengaruhi pembesaran, pemanjangan dan pembelahan sel serta mempengaruhi metabolisme asam nukleat dan metabolisme protein $[9,10]$. Taraf auksin dalam sel tergantung dari bagian tanaman yang diambil, jenis tanamannya dan umur tanaman. Pengaruh fisiologis auksin yang lain adalah penghambatan tunas lateral akibat peran auksin 
dalam dominansi apikal, yang bergerak dari bagian apikal secara basipetal [10].

Sitokinin merupakan ZPT yang mendorong pembelahan (sitokinesis), pertumbuhan dan perkembangan kulktur sel tanaman. Sitokinin juga menunda penuaan daun, bunga dan buah dengan cara mengontrol dengan baik proses kemunduran yang menyebabkan kematian sel-sel tanaman. Pada tumbuhan, efek sitokinin sering dipengaruhi oleh keberadaan auksin, misalnya jumlah akar yang banyak akan menghasilkan sitokinin dalam jumlah banyak [8] Peningkatan konsentrasi sitokinin ini akan menyebabkan sistem tunas membentuk cabang dalam jumlah yang lebih banyak.

Pada penelitian ini dicobakan berbagai kombinasi zat pebgatur tumbuh untuk memacu regenerasi tanaman gloxinia (Siningia speciosa) secara in vitro dan diharapkan dapat diperoleh formula yang cocok untuk perbanyakan tanaman gloxinia.

\section{METODE PENELITIAN}

Bahan yang digunakan berupa eksplan batang dan tunas gloxinia (yang telah diperbanyak sebelumnya pada media MSO), media MS, gula, fulvic acid, auksin, sitokinin (BA, Novelgro dan air kelapa).

Tanaman gloxinia dikeluarkan dari botol kultur dengan menggunakan pinset, kemudian dipindahkan ke cawan yang telah diberi $5 \mathrm{ml}$ air steril dan satu tetes betadine. Batang dan tunas dipotong, kemudian ditanamkan pada media MS yang telah diberikan tambahan ZPT sebagai perlakuan Tabel 1). Pada setiap botol kultur ditanam dua eksplan (batang atau tunas).

Perlakuan yang digunakan adalah kombinasi ZPT yang terdiri dari auksin, fulvic acid dan sitokinin. Auksin yang digunakan yaitu NAA (0; 2,$\left.5 ; 5,0 \mathrm{mgl}^{-1}\right)$, fulvic acid $\left(0 ; 1,0 \mathrm{mgl}^{-1}\right)$ dan sitokinin (BA $5 \mathrm{mgl}^{-1}$; Novelgro $5 \mathrm{mll}^{-1}$; air kelapa 20\%). Setiap perlakuan diulang 10 kali. Pengamatan dilakukan setiap minggu sampai kultur berumur 8 minggu. Peubah yang diamati terdiri dari pembentukan tunas (jumlah tunas) dan jumlah daun.

\section{HASIL DAN PEMBAHASAN}

Secara keseluruhan, eksplan gloxinia yang ditanam dapat tumbuh membentuk tunas dan daun pada semua perlakuan, tetapi dengan tingkat pertumbuhan (persentase rata-rata pembentukan tunas dan rata-rata jumlah daun) yang berbeda-beda. Eksplan yang tumbuh diawali dengan semakin membesarnya ukuran eksplan dan warnanya menjadi hijau segar, pada luka bekas potongan terjadi pembengkakan (kalus) dan selanjutnya tumbuh menjadi tunas adventif. Ukuran eksplan juga mempengaruhi tingkat persentase pertumbuhan tunas dan potensi morfogenesis eksplan. Eksplan yang kecil ukurannya daya tumbuhnya kurang bila dikulturkan.

Tabel 1. Komposisi ZPT yang ditambahkan pada media MS untuk berbagai perlakuan

\begin{tabular}{|c|c|c|c|}
\hline Media & $\begin{array}{c}\text { NAA } \\
\left(\mathrm{mgl}^{-1}\right)\end{array}$ & $\begin{array}{c}\text { Fulvic acid } \\
\left(\mathrm{mgl}^{-1}\right)\end{array}$ & Sitokinin \\
\hline 1 & 0 & 0 & BA $5 \mathrm{mgl}^{-1}$ \\
\hline 2 & 0 & 0 & Novelgro $5 \mathrm{mll}^{-1}$ \\
\hline 3 & 0 & 0 & Air kelapa $20 \%$ \\
\hline 4 & 0 & 1 & BA $5 \mathrm{mgl}^{-1}$ \\
\hline 5 & 0 & 1 & Novelgro $5 \mathrm{mll}^{-1}$ \\
\hline 6 & 0 & 1 & Air kelapa $20 \%$ \\
\hline 7 & 2,5 & 0 & BA $5 \mathrm{mgl}^{-1}$ \\
\hline 8 & 2,5 & 0 & Novelgro $5 \mathrm{mll}^{-1}$ \\
\hline 9 & 2,5 & 0 & Air kelapa 20\% \\
\hline 10 & 2,5 & 1 & BA $5 \mathrm{mgl}^{-1}$ \\
\hline 11 & 2,5 & 1 & Novelgro $5 \mathrm{mll}^{-1}$ \\
\hline 12 & 2,5 & 1 & Air kelapa 20\% \\
\hline 13 & 5,0 & 0 & BA $5 \mathrm{mgl}^{-1}$ \\
\hline 14 & 5,0 & 0 & Novelgro $5 \mathrm{mll}^{-1}$ \\
\hline 15 & 5,0 & 0 & Air kelapa 20\% \\
\hline 16 & 5,0 & 1 & BA $5 \mathrm{mgl}^{-1}$ \\
\hline 17 & 5,0 & 1 & Novelgro $5 \mathrm{mll}^{-1}$ \\
\hline 18 & 5,0 & 1 & Air kelapa $20 \%$ \\
\hline
\end{tabular}

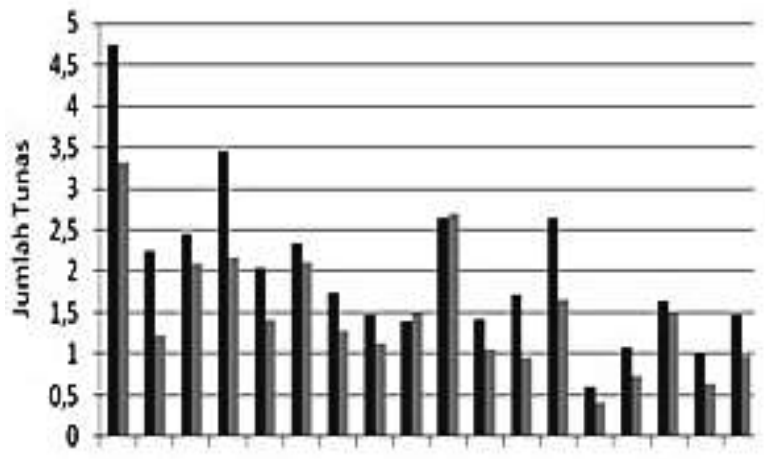

12345678991012131415161718

Media

\section{- Tanamana}

Gambar 1. Rata-rata jumlah tunas gloxinia pada berbagai media

\section{Pembentukan Tunas Gloxinia}

Jumlah tunas gloxinia yang terbentuk dan diamati pada semua perlakuan menunjukkan tingkat pertumbuhan yang berbeda-beda. Pada hasil pengamatan terlihat bahwa pada Media 1 
(M1) yang hanya diberi perlakuan BA $5 \mathrm{mgl}^{-1}$ menunjukkan pembentukan tunas yang paling baik, dimana jumlah tunas yang terbentuk paling banyak dibandingkan perlakuan yang lain (Gambar 1). Pada Gambar 1 terlihat bahwa umumnya jumlah tunas yang terbentuk pada perlakuan sitokinin saja (M1 - M6) memberikan jumlah tunas yang lebih banyak. Hal ini menunjukkan bahwa sitokinin merupakan hormon tumbuh yang mempengaruhi pembelahan sel. Menurut Skoog dan Miller (1957) dalam Nurhayati (1987) bahwa terbentuknya tunas diperlukan sitokinin yang tinggi tanpa atau dengan sedikit auksin. Sitokinin baik faktor tunggal maupun kombinasinya dengan auksin dalam kultur jaringan berperan dalam menginduksi maupun penggandaan tunas (Winarsih dan Priyono, 2000) Hal ini menunjukkan bahwa auksin endogen sudah cukup tersedia untuk menstimulir pembentukan akar [11].

Pembentukan tunas paling sedikit ditunjukkan oleh Media 14 (M14) dengan kombinasi perlakuan NAA $5 \mathrm{mgl}^{-1}+$ Novelgro 5 $\mathrm{mll}^{-1}$. Hal ini menunjukkan bahwa pada tumbuhan, efek sitokinin sering dipengaruhi oleh keberadaan auksin. Sebagian besar tanaman memiliki pola pertumbuhan yang komplek yaitu tunas lateral tumbuh bersamaan dengan tunas terminal. Menurut Karjadi dan Buchory (2007), pola pertumbuhan tanaman merupakan hasil interaksi antara auksin dan sitokinin dengan perbandingan tertentu. Sitokinin diproduksi dari akar dan diangkut ke tajuk, sedangkan auksin dihasilkan di kuncup terminal kemudian diangkut ke bagian bawah tumbuhan [8].

Auksin cenderung menghambat aktivitas meristem lateral yang letaknya berdekatan dengan meristem apical sehingga membatasi pembentukan tunas-tunas cabang dan fenomena ini disebut dominasi apical [13]. Kuncup aksilar umumnya mulai terbentuk pada ketiak daun yang terdapat di bagian bawah tajuk (daerah yang berdekatan dengan akar) dan biasanya akan tumbuh memanjang dibandingkan dengan tunas aksilar yang terdapat dekat dengan kuncup terminal [14]. Hal ini menunjukkan rasio sitokinin terhadap auksin yang lebih tinggi pada bagian bawah tumbuhan.

Interaksi antara auksin dan sitokinin juga merupakan salah satu cara tumbuhan dalan mengatur derajat pertumbuhan akar dan tunas.

Pembentukan Daun Gloxinia

Hasil pengamatan pada jumlah daun menunjukkan bahwa hampir semua perlakuan
NAA dan Fulvic acid yang dikombinasikan dengan air kelapa memberikan pertumbuhan jumlah daun yang lebih tinggi dibandingkan kombinasi perlakuan lainnya. Hasil tertinggi diperoleh pada Media 3 (NAA $0 \mathrm{mgl}^{-1}+$ Fulvic acid $0 \mathrm{mgl}^{-1}+$ Air kelapa 20\%) dan Media 6 (NAA $0 \mathrm{mgl}^{-1}+$ Fulvic acid $1 \mathrm{mgl}^{-1}+$ Air kelapa 20\%), sedangkan hasil terendah ditunjukkan oleh perlakuan Media 14 (Gambar 2).

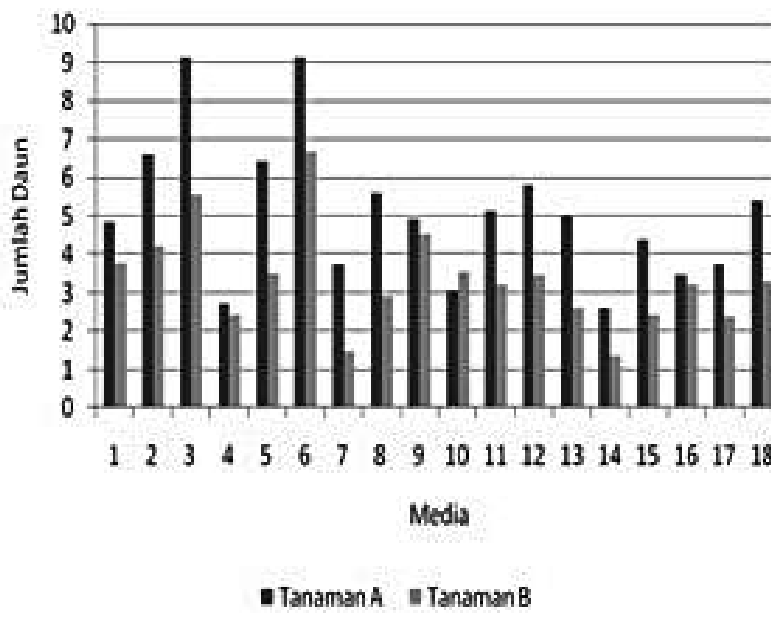

Gambar 2. Rata-rata jumlah daun tanaman gloxinia pada berbagai media

Hal ini menunjukkan bahwa air kelapa memiliki manfaat untuk meningkatkan pertumbuhan tanaman. Air kelapa yang sering dibuang ternyata dapat dimanfaatkan sebagai penyubur tanaman.

Selama ini, air kelapa banyak digunakan di Laboratorium sebagai nutrisi tambahan di dalam media kultur jaringan. Hasil penelitian menunjukkan bahwa air kelapa kaya akan kalium hingga $17 \%$. Selain kaya mineral, air kelapa juga mengandung gula antara $1,7-2,6 \%$ dan protein $0,07-0,55 \%$. Mineral lainnya yang terdapat di dalam air kelapa antara lain natrium ( $\mathrm{Na})$, kalsium (Ca), magnesium (Mg), ferum (Fe), cuprum (Cu), fosfor (P) dan sulfur (S). Air kelapa juga mengandung berbagai macam vitamin seperti asam nitrat, asam nikotinat, asam pantotenat, asam folat, niacin, riboflavin dan thiamin [15]. Terdapat pula 2 hormon alami yaitu auksin dan sitokinin sebagai pendukung pembelahan sel embrio kelapa.

Penelitian yang dilakukan oleh National Institute of Molecular Biology and Biotechnology (BIOTECH) UP Los Banos mendapatkan bahwa dari air kelapa dapat diekstrak hormon yang kemudian dapat dibuat suatu produk suplemen yang disebut cocogro [16]. Hasil penelitian itu 
menunjukkan produk hormon dari air kelapa ini mampu meningkatkan hasil kedele hingga 64\%, kacang tanah hingga 15\% dan sayuran $20-30 \%$. Dengan adanya kandungan unsur kalium yang cukup tinggi, air kelapa dapat merangsang pembungaan pada anggrek.

Patiroi (1992) juga melakukan penelitian yang mengujicobakan air kelapa muda dengan konsentrasi yang berbeda $(0,20 \%, 40 \%, 60 \%$, $80 \%)$ untuk merangsang pertumbuhan algae dengan menggunakan fitoplankton jenis Skeletonema costatum. Hasil penelitian menunjukkan bahwa dari kelima konsentrasi yang diicobakan ternyata konsentrasi $40 \%$ air kelapa muda memberikan kelimpahan Skeletonema costatum tertinggi, selanjutnya berturut-turut $60 \%, 80 \%, 20 \%$ dan $0 \%$ memperlihatkan penurunan kelimpahan dari Skeletonema costatum. Berdasarkan hasil penelitian itu disimpulkan bahwa pemberian sitokinin bermanfaat dalam mempercepat pertumbuhan dan perkembangan Skeletonema costatum sampai konsentrasi tertentu. Konsentrasi yang terlalu tinggi atau rendah justru tidak memberikan efek positif [17].

\section{KESIMPULAN}

Pembentukan tunas dan daun dipengaruhi oleh komposisi zat pengatur tumbuh yang digunakan yaitu auksin dan sitokinin. Jumlah tunas terbanyak ditunjukkan oleh eksplan yang mendpat perlakuan BA $5 \mathrm{mgl}^{-1}$ (M1) dan perlakuan sitokinin saja tanpa auksin (M1 - M6) memberikan jumlah tunas yang lebih banyak dibandingkan perlakuan yang mendapat auksin. Jumlah daun tertinggi diperoleh pada Media 3 $\left(\right.$ NAA $0 \mathrm{mgl}^{-1}+$ Fulvic acid $0 \mathrm{mgl}^{-1}+$ Air kelapa $20 \%$ dan Media 6 (NAA $0 \mathrm{mgl}^{-1}+$ Fulvic acid $1 \mathrm{mgl}^{-1}+$ Air kelapa 20\%). Hampir semua perlakuan NAA dan Fulvic acid yang dikombinasikan dengan air kelapa menunjukkan pertumbuhan jumlah daun yang lebih tinggi dibandingkan kombinasi perlakuan lainnya.

\section{DAFTAR PUSTAKA}

1. Crockett J.M. 1974. Flowering House Plants. Time Life Books. New York.

2. Larouse. 1995. Complete Guide to Indoor Plant : the most complete and practical colour guide to over 500 conservatory \& indoor plant. Larouse pcl.

3. McHoy P. 1995. The complete House Plant Book :the essential guide to successful indoor gardening. Anness Publishing, Ltd. London.
4. Syafni. 2006. Induksi Keragaman Genetik Gloxinia (Siningia speciosa. Benth) melalui Radiasi Sinar Gamma. [Tesis]. Bogor: Sekolah Pascasarjana, IPB.

5. Saraswati R.D. 2006. Pengaruh sinar ultraviolet dan fotoperioda terhadap pertumbuhan dan perkembangan kultur in vitro mawar mini (Rosa hybrida L.). Undergraduate Theses dari JBPTITBRI. Bandung: Sekolah Ilmu dan Teknologi hayati. ITB. Bandung.

6. Purwito A., Muklisa P., Maharijaya A. 2005. Perbanyakan Ruskus (Ruscus hypophyllum L.) secara in vitro. Bul. Agron. 33. 2:39-45.

7. Lizawati, Novita T., Purnamaningsih R. 2009. Induksi dan Multiplikasi Tunas Jarak Pagar (Jatropha curcas L) Secara In Vitro. Jurnal Agron. Indonesia 37. 1:78-85.

8. Karjadi A.K., Buchory A. 2007. Pengaruh NAA dan BAP terhadap Pertumbuhan Jaringan Meristem Bawang Putih pada Media B5. Jurnal Hort. 17. 3:217-223

9. Moore C.T. 1979. Biochemistry and Physiology Plant Hormone. Springer - Verlag New York, Inc. New York.

10. Davies P.J. 2004. Plant Hormones. Kluwer Academic Publishers. Dordrecht Boston London.

11. Nurhayati A.M. 1987. Keseimbangan Konsentrasi Auksin dan Sitokinin dengan Inhibitor Ancymidol pada Perkembangan Bahan Tanaman Dianthus caryophyllus Linn secara In Vitro. Tesis. Fakultas Pascasarjana IPB. Bogor.

12. Winarsih S.P. 2000. Pengaruh Zat Pengatur Tumbuh Terhadap Pembentukan dan Pengakaran Tunas Mikro pada Asparagus secara In Vitro. Jurnal Hort. 10. 1:11-17.

13. Catala C, Rose JKC, Bennett AB. 2000. AuxinRegulated Genes Encoding Cell Wall Modifying Proteins are Expressed During Early Tomato Fruit Growth - Plant. Physiol. 122:527-534.

14. Winarto B. Rianawati S. Herlina D. 2007. Pengaruh Media Regenerasi terhadap Pembentukan Tunas Aksilar dan Adventif pada Philodendron c.v. Moon Light. Jurnal Hort. 17. 1:8-16.

15. Sri Djayawati. 1993. Pengaruh Penggunaan Air Kelapa Muda dan Hydrasil Terhadap Laju Pertumbuhan Rumput Laut (Gracilaria verocosa). Tesis. Jurusan Budidaya Perairan. Fakultas Perikanan UMI. Ujung Pandang.

16. Mindforum. 2009. http://www.mindforum. com. Air Kelapa Pemacu Pertumbuhan dan 
Pemberian Kombinasi ZPT terhadap Regenerasi Gloxinia Secara In Vitro (Lawalata, I.J.)

Pembungaan Anggrek. Tanggal akses 20 Juli 2010.

17. Patiroi S. 1992. Pengaruh Penggunaan Air Kelapa Muda Terhadap Kelimpahan Skeletonema costatum. Tesis. Jurusan Perikanan Universitas Hasanudin. Ujung Pandang. 